\title{
A Study of Al-Qur'an Interpretation About Grateful and Bakheel (Stingy) Personalities in Human Life
}

\author{
Syaiful Amry ${ }^{1 *}$, Aris Fauzan ${ }^{2}$
}

\author{
${ }^{1}$ Student of Graduate School, Faculty of Islamic Studies, University Muhammadiyah of Yogyakarta, Indonesia \\ ${ }^{2}$ Lecturer of Graduate School, Faculty of Islamic Studies, University Muhammadiyah of Yogyakarta, Indonesia \\ ${ }^{*}$ Corresponding author. Email: syaiful.amry.pascal8@mail.umy.ac.id.
}

\begin{abstract}
Psychologists look into a human personality as permanent psychological structure and process by structuring the experience of each individual and shaping the various actions and responses of the individual to the environment in which he lives. During a person's growth, his personality grows dynamically, changing along with the influence of the environment, life experience and education. Through a long life process a personality is formed. The Islamic personality is a series of normative human behavior, both as an individual and as a social being, in which case norms are derived from Islamic teachings from the Al-Qur'an and AsSunnah. In human life, there are good and bad behaviors that are in conflict with one another. An example of good personality is gratitude, and an example of bad one is bakheel (stinginess). - This study used supporting literature as research material. There are two sources of data for this research, the Al-Qur'an and its translation as the primary data source and Al-Azhar interpretation by Buya Hamka as the secondary data source. The perspective of the Al-Qur'an needs to be studied with the consideration that the Al-Qur'an is the personality of God's intelligence that is worth to be used as a guideline, of values for humans. The Al-Qur'an provides a comprehensive view, that humans have physical, soul, mind, heart, and spirit potentials. Thus, a need to study the AlQur'an arises, especially on verses that are closely related to psychology. In this case, the verses are about gratitude and stinginess as human domains in social life in the world. The purpose of this research is to bring up a new perspective in psychology under the influence of the Al-Qur'an. This research will fill the gap in psychology for humans and society. The study of human psyche is a useful scientific activity and should be encouraged as should be other sciences.
\end{abstract}

Keywords: Personality, Gratitude, Bakheel

\section{INTRODUCTION}

Psychologists view a human personality as a permanent psychological structure and process by structuring the experience of each individual and shaping the various actions and responses of the individuals to the environment in which he lives. During a person's growth, his personality grows dynamically, changing along with the influence of the environment, life experience and education. Through a long life process a personality is formed.

Personality, Gordon W. Allport (an American psychologist) says, "is the dynamic organization within the individual of those psychophysical systems that determines his unique adjustment of his environment." He explains that personality is a dynamic characteristic with its uniqueness regarding the time dimension and individual environment in which it is located. Personality is an individual characteristic that is influenced by life experience and learning so that it can change the individual's character for the better or for the worse.

The Islamic personality is a series of normative human behaviors, both as an individual and as a social being, which are normally derived from the Islamic teachings the AlQur'an and As-Sunnah. Al-Ghazali, a Muslim philosopher, says that the personality structure is comprised of lust, reason and heart, and one should follow the Al-Qur'an and AsSunnah to form a consistent personality, including in his faith, Islamic religion, worship and mu'amalah to the pleasure of Allah.

In human life, there are good and bad behaviors that are in conflict with one another. An example of good personality is gratitude, while bad personality can be exemplified by stinginess. The English word gratitude is taken from the Latin gratia, which means gentleness, kindness, or gratitude. All the words that form from this Latin root have a close connection with goodness, giving, and the beauty of giving and receiving. (Puyer, Emmons \& McCullough, 2003).

Gratitude is a positive emotion that is associated with the kindness of others (Bartlett \& DeSteno, 2006; Larson, \& Kilpatrick 2001). Across eastern and western cultures and religions, gratitude is considered a "fundamental and valuable aspect of human personality and social life" (Emmos \& McCullough 2003). In psychology, recent research shows gratitude as having a variety of positive effects, such as increasing prosocial behavior, maintaining intimate bonds, and improving psychological and physical well-being (Emmons et al. 2003).

From the age of humor to the real, scholars have struggled with gratitude as a human trait. Several world religions teach 
about the importance of gratitude (Emmons \& Crumpler, 2000). However, gratitude has escaped the full attention of psychologists almost completely (McCullough, Emmons \& Tsang, 2002). Research shows that gratitude is important to people (Gallup, 1998) and that it is a highly valued trait. McCullough and colleagues define the disposition of gratitude as a general tendency to recognize and respond with positive emotions (appreciation, gratitude) to the role of goodness of other moral agents in one's experiences and positive outcomes. Bartlett and DeSteno (2006) define evidence that gratitude plays an important role in facilitating costly behavior in ways that are different, from general positive states or simple awareness of prosocial norms.

According to Emmons and McCullough (2003), gratitude is a form of feeling or emotion, which then develops into an attitude. It then becomes a good moral character, turns into a habit, produces personality traits, and finally affects a person to react or respond to a situation. Emmons also adds that gratitude leads to happiness, makes you feel good, and can trigger motivation. According to Wood (2009) gratitude is a form of personal trait whereby one thinks positively and also represents life to be more positive.

Gratitude occupies the highest position among other praiseworthy attributes. An Islamic philosopher Al-Ghazali, places gratitude above zuhud, patience and other traits. The meaning of gratitude can be manifested in a compliment to the source who gives to the giver or by saying thank you. Gratitude is the declaration of the blessings of Allah made by His servants. It verbally means showing gratitude with praise and acknowledgment, from witnessing and feeling pleasure and gratitude for the body, by submitting and obeying His commands.

Gratitude can also be interpreted as self-awareness that everything that has been done is considered not of any value. even though it has been done optimally. While what is received is considered a lot, even though in reality it is little. Based on the ideas of the experts above, it can be concluded that gratitude is one's acknowledgment of the existence of another party or source who contributed to the blessings received, so it can encourage him to give praise or give thanks to that party or source for doing him good.

On the contrary to good personality, there is also bad personality, including stinginess. The Arabic bakheel means parsimony. This term describes the despicable nature of a person who is reluctant to spend money that must be issued. A person can be considered stingy in the Islamic view for two reasons, first, if she does not spend his wealth on himself and his family according to his ability and second, if she does not spend his assets for the purpose of social goodness in society even though he has the ability. Humans like this are considered not grateful for the blessings of Allah.

An ideal society as mentioned first above will only be realized when thoughts and actions are built on solid and straight faith as the basis for intrapersonal communication, because true faith will encourage one to manifest goodness for herself and her environment through various realities of action and behavior. Meanwhile, someone who does not stand on the basis of faith in thinking and acting will only develop selfishness and stinginess. This stingy nature is something to hate from the prophetic perspective.

\section{METHODS}

We used qualitative research methods. The data source of this research was Al-Azhar interpretation by Buya Hamka. The authors examined verses about the personalities of gratitude and stingy one by one. Other tools or sources the authors used to support this research were a collection of credible articles, journals and books. The purpose of using those additional sources were to generate research results that were worthy of usage. The methods we used bad to be in accordance with the title or the results that we will describe later

\section{RESULTS}

\subsection{Verses on Gratitude}

\subsubsection{Surah Ibrahim Verse 7}

"And (remember) when you have given your Lord your remembrance: Behold, if you are grateful, you will be added to It". According to the Al-Azhar interpretation by Buya Hamka of Surah Ibrahim verse 7, one should keep trying to overcome difficulties in gratitude. $\mathrm{He}$ is told against grumbling over insufficient supplies and complaining if what he is trying to achieve has not been achieved. He must give thanks for that, so Allah will surely add to it. If he just complains, that he is lacking, and that the thing he is pursuing has not been achieved as if Allah's help is not coming soon, then that is kufr, meaning that he is forgetting favors and ungrateful. Such a person will be subject to grievous torments and horrors. Among such torments is his soul being in agony because he is afflicted with an illness, and always feels dissatisfied.

\subsubsection{Surah Luqman Verse 12}

The Al-Azhar interpretation of Surah Luqman verse 12 explains that Luqman had been given wisdom. He had been able to do a charity with his own knowledge. He was ordained to "give thanks to Allah!" This was the pinnacle of wisdom that he had found. He knew from either experience of his own or from learning the experience of others that Allah's blessings covered his whole life. Therefore there was no other way for him to be grateful. It is humble of a man to know that his whole life is covered by Allah's blessings, even though he might not be aware of all of them. "And whoever is grateful," for the various kinds of favors and graces given by Allah, which are uncountable, from the time he was born into the world and his life, until he was put behind the earth - "then, he is grateful (for the benefit of) himself". Anyone who remembers and appreciates the services of others to himself, is counted as a wise person. The one who gives pleasure and grace is Allah himself.

Therefore, being grateful will enhance one's own value, which is only proper and natural for a person who is aware of his/her self-worth. "And whoever is kufr," - or ungrateful, not commemorating merit, and unthankful - "then verily Allah is 
the Most Rich," Allah will never be lacking in His wealth just because there are servants who do not remember Him. The only loser is the servant who is ungrateful Allah, on the other hand, has nothing to lose. Angels, unknown though their number is in the sky and on earth, and some other creatures always say tasbih and praise to Allah the "Most Praised.". He is praised by people who are wise.

\subsubsection{Surah Al-Baqarah Verse 152}

"Then remember Me, I will also remember you." It was narrated by Abu asy-Shaykh and ad-Dailami from Jalan Jubair as he received from ad-Dhahhak, that Ibn Abbas interpreted this as: "Remember Me, My servants, by obeying Me; surely I will remember you by giving you mercy." This was interpreted by Abu Hindun ad-Dari, as described by Ibn'Asakir from ad Dailami, according to a Hadith as follows: "Then whoever remembers Me- and follows Me obediently, it is My duty to remember that remembrance by remembering him too and-by giving him forgiveness. And whoever remembers $\mathrm{Me}$, but he commits disobedience (immoral deeds), I will also remember him by threatening him. "

"And be thankful to Me, and do not become disobedient to Me." One should be thankful for the nikma He bestows, upon him by giving thanks. This gratitude should be expressed not only by mouth, but also by deeds. It is a pleasure to be grateful and Allah promises to add more. Additionally, he must not have low morals, such as failing to feel grateful. Being ungrateful for Allah's favors is kufr. If he is not grateful for the blessings that Allah has bestowed upon him, it is easy for Allah to take such blessings back, and turn him in the dark.

\subsubsection{Surah An-Nahl Verse 78}

"And Allah has taken you out of the stomachs of your mothers, knowing nothing." Humans face the darkness of this world and only with tears do they face the world when they come out of their mother's stomachs. There is nothing that they know, apart from the Divine grace called gharizah or instinct. they crying when they are cold, hungry, or hot: "And He made it for you hearing and seeing and the heart." Gradually hearing develops, and voices are heard from near to far; Then vision develops, so that they can distinguish one color from another, and observe the faces of the mothers who are nursing them. Hearing and vision are guided by the development of the heart, or the feelings and thoughts. They grow up over time, until they become human beings who are wise, polite, courteous, and able to carry out taklif, or the responsibility imposed by Allah on their shoulders, to become part of humanit. "so that you (they) are grateful."

Humans are born into the world, with hearing, so that they are not deaf, and with vision, so they are not blind. They are also given the heart to consider what they hear and see. Hearing, vision, and the heart are the greatest blessings bestowed by Allah in their life. These blessings are given because humans are bearing a heavy task, of becoming khalifatullah on earth. Being grateful means making the best use of Allah's blessings in this world, to become meaningful human beings. Gratitude means gratefulness and the opposite of gratitude is $k u f r$, which is not knowing one's mind.

\subsubsection{Surah Al-Qasash Verse 73}

"And half His mercy He made for you is night and day." It is stated in this verse that the succession of day and night is half of the Mercy of Allah which is benefical to the body. If there is no alternation between day and night, human beings cannot exist in this world. The succession of day and night proves that Allah is alive. If Allah is not alive, it is certain that nothing will regulate the circulation of the universe; "So that you rest", that is, at night. While you are tired, of work and of the heat of the sun during the day, you can rest at night. A few hours of deep sleep brings back freshness to the nerves. It is not only the body that is resting, but also the mind. "And so that you may receive from some of His gifts." that is during the day. Because when you wake up early in the morning and a new day comes, your body is refreshed to start a new work and business. Life on earth is an endeavor and work, Allah provides everything humans need on earth, in order to sustain their life.

\subsubsection{Surah Al-Qamar Verse 35}

"As a pleasure from Us". Those who are obedient to Allah, who are faithful to keep to His commandments and who stop doing what is forbidden, even though their number is small compared to the number of those who are disobedient (and those few are kept by Allah, are given the gift of salvation and freedom. "Thus We reward those who are grateful." This gives an impression that those who have been faithful to the truths revealed by Allah, are not to worry about any dangers. They do not have to worry, because they will survive. All verses in the Al-Quran that contain threats to sinners, always come with exceptions for those who are steadfast in obeying Allah's commands.

\subsubsection{Surah Az-Zumar Verse 66}

"Therefore, let Allah be the One your worship is due." Allah alone is God, there is no other God. And He is the Creator. Therefore, He has the right to be worshiped. This is the essence of religion. This is submission that arises from consciousness of Allah, the Almighty God. "And include you in the class of those who are grateful." Because with belief, faith and piety. That which deserves to be worshiped is only One, it becomes clear that gratitude is due to the One God and no one else.

\subsubsection{Surah Al-Furqan Verse 62}

"And He (also) who makes night and day alternate for people who want to take lessons or people who want to be grateful". Shaykh As Sa'diy rahimahullah said, "Behold, the heart changes and moves at night and day. Sometimes there is enthusiasm and sometimes it appears lazy. Sometimes it appears in remembrance and sometimes itu appears negligent. Sometimes it appears narrow and sometimes it appears broad. Sometimes it appears to and sometimes it appears turned away. Then Allah makes night and day pass through the servants and comes over and over again so that there will be remembrance enthusiasm and gratitude to Allah at other times. Besides that the wazifa of worship is repeated with repeated nights and days. Every time the time is repeated, 
there arises for me a desire that is not a desire that was weakened in the past, so that my memory and gratitude will increase. The duties of obedience are like a shower of faith that helps me. If there is no task, the plant of faith will wither and dry up. Then the most perfect and complete praise for it belongs to Allah."

\subsubsection{Surah Al-Imran Verse 145}

"Something that has life will not die but with the permission of Allah, at a predetermined time. Whoever wants the rewards of the world, surely We will give him the rewards of the world, and whoever wants the rewards of the hereafter, We give (also) him the rewards of the hereafter. And we will give back to those who are grateful". Something that is alive will not die but with the permission and determination of Allah, as a predetermined time. Whoever wants the reward of the world like ghanimah and others, surely Allah will give him the reward of the world, and whoever wants the reward of the hereafter, which is heaven, then Allah gives (also) to him the reward of the hereafter with its goodness many times over. And Allah will give generous returns to those who are grateful. That is, those who remain steadfast in their religion and obey His Lord's commands by fighting and being patient. These people are called people who are grateful for Allah's blessings. They will be rewarded according to the degree of their gratitude.

\subsubsection{Surah Al-Baqarah Verse 172}

"O you who believe, eat among the good sustenance that We give to you and give thanks to Allah, if you really worship Him". Good food is always provided by God as long as one works on it. Fruits grows, and so do farm animals. As long as he tries to find and choose the good among foods he will certainly not be short of food. "And give thank's to Allah", because everything is provided by Allah. According to the investigations of nutritionists, various foods contain several kinds of vitamins, iron, acids, calories and hormones among other things, all of which will strengthen the human body. Therefore, give thanks to Allah, "If it is only Him you will worship."

\subsection{Verses on Bakheel}

\subsubsection{Surah Muhammad Verse 38}

"You have been called to spend your wealth in the way of Allah, so half of you are stingy." In gatherings one might always be present, but when he is asked to make a sacrifice, he turns into a complete silence. "Then whoever is stingy", or whoever is unkind, has a difficulty making a charity out of his money, even though it is easy for him to spend on personal interests. The meaning is that people are stingy. Stinginess is not beneficial to one's self, but harmful. The stingy become people's ridicule. This temperament becomes reproachful when it meet a person, and it becomes even more despicable and undermining to the dignity of a nation, when it meets the nation. "And Allah is the Most Rich and you are very destitute." This warning is given by Allah to humans in an expression which is very important in meaning to educate them in eliminating the "mental illness" called stinginess. In this expression, Allah warns that the very rich is Him, and humans have nothing.

Finally, as a closure Allah says,:"And if you turn away", to refer to a condition in which one turns away as in leaving an initial position. That is moving away from a priority to common interests to a priority to self interests. Given that man as a person has nothing, if this condition is fulfilled, "surely He will replace you (him) with another people." The other people is comprised of those who are able to hold fast to the mandate of Allah, and who are able to inherit the wealth; "and those other people will not resemble you (him)."

\subsubsection{Surah An-Nisa Verse 37}

"(Namely) people who are Stingy and order people to be stingy too", are humans who have begun to move beyond Allah's line. The utmost disease is stinginess. This too has become a shadow of shirk. Those who are stingy love wealth more than they do Allah who has purified the wealth. Such people want to take as much from society as possible, but gives very little. Their bakheel is also enjoined upon others. They praise their own mistakes, saving that those are the right things. "And hid what Allah has given them from His grace." What has entered into their coffers is not likely to come out again. The item will come out later after they die, to be shared by other swimmers. They become stingy, because their love has spilled on that treasure alone. With Allah who has purified their wealth, they are no longer in love. Mothers and fathers, families, neighbors near and far, orphans and poor people, they do not. If they have friends, in addition to what is said in the previous verse, it is only because those friends will bring profit and wealth to them. So their stinginess has approached the gate of $k u f r$, which is very dangerous.

Hiding what Allah has given, is not limited only to stinginess with money, it goes beyond that. For example, a person has mastered an extensive body of knowledge religion and lives in a village or country where the population does not understand religion, but he does not want to teach the population that knowledge.

\subsubsection{Surah Al-Isra' Verse 100}

"Say, "if you have a treasure trove of the mercy of my Lord. ", if for example you are given riches by Allah, full of treasures and deposits, and take your gold and silver as a gift from Allah;" instantly you will undoubtedly hold it, for fear of it being spent." This is a disease that arises from kufr too. You have received Allah's grace, but enjoyed it alone, being afraid to share it with others. This verse closes with: "And man is miserly".

This is human instinct. There is only one cure for it, namely faith in Allah and love for fellow humans. And one who is miserly unconsciously, has grown in his own breast a seed of shirk, or an associate to Allah. Because of his love for the treasures that have been given by Allah, he has grown negligent and careless and forgot Allah who gives Mercy. 


\subsubsection{Surah Al-Hadid Verse 24}

"(Namely) people who are misers and enjoin miserliness upon other people." The stingy are reluctant to take out the property that is in their hands to help someone who is in trouble, even though they have the ability. The person who encourages other people to be stingy like him is in modern times called "egoistic" or selfish. This is despite at some time he expecting other people's help. Humans will not be able to live alone in this world. Therefore at the end of the verse Allah says, "And whoever turns away", as in not wanting to help other people, and holding back inviting other people to miserliness. "So infact Allah is the Most Rich, the Most Praiseworthy."

The end of this verse is a very important medicine for people who are strong in spirit. If it is obvious that a person is a miser, then do not ask him, instead ask Allah as stated in the famous verse: "Do not ask your fellow children of Adam if you have an urge, but ask Allah whose door is never closed. Allah is very angry. if you leave begging Him. While the Son of Adam, if we ask him he is angry". There is also a mention of Allah's nature, the Most Praiseworthy, in the end of the verse. People who truly trust in Him, must be given blessings, there is no doubt about this.

\subsubsection{Surah At-Taghabun Verse 16}

"And whoever is preserved from his stinginess, they are the lucky ones". Miserliness and stinginess mean the same thing. Those are the temperament of people who are reluctant to spend their property and who feel that it is hard to divorce themselves from their money. They find it difficult to take from their savings, especially to help people who are in trouble, or are poor. They let the person who asks for help go home empty-handed.

According to investigations in psychology, this disease of shuhha or miserliness comes into each human being through, what is in Arabic called ghariizah or by Western people called instinct. It must be present in each person because it is part of ghariizah to sustain life or survive. If a poor person appears to come from afar, in dirty clothes with a pale face, being lethargic from hunger, then the first thing comes to one's mind is disgust or displeasure, thinking to himself. "Ah, this person is about to ask for charity too!" With faith and practice it is obligatory for a believer to control himself not to have such an instinct influence him, and make him contact a disease named miserliness. If we want to survive with our possessions, then we must realize that possessions that we have in excess should be given to others who want to survive as well.

\subsubsection{Surah Al-Imran Verse 180}

"And don't those who are miserly think that what Allah has given them from His gift, is what is good for them." This verse is a strong warning to the miser, to change their way of thinking. Allah has given them a gift, but still after that gift is received they are reluctant to give a modest portion of that gift to others. They are reluctant to spend Allah's gift to them, for the general public. They say that keeping for themselves is good. The first evil against them is that they cannot benefit from the treasure. The treasure dies. Unconsciously they have been enslaved by the treasure themselves, despite their labor to search for it. There is loss of love, and there is even hatred, when people come to ask for help.

\subsubsection{Surah At-Taubah Verse 76}

"But when He gave them some of His gifts", and led them from poverty to prosperity, from misery they came to live happily because the wealth was already there. In the past, they lived marginalized lives, but now they rise to the middle class, because Allah has granted their wishes, although only partially. However, "they are miserly with it." They begin to forget the promise that they said when they were still poor. They said a promise to Allah, and then Allah grant their request, giving a portion of wealth. Over time, however they forget their promises, and forget that it was Allah Himself who raised them from the pit of poverty. They came to think that the treasure was their own that they felt good earning by exerting themselves, and they found it hard to spend some on charity. When people come to ask for charity, they start to be reluctant to give. They find ways to get away from that promise they have said to Allah. So the miser's illness grows deeper and deeper. They grow increasingly bored and even afraid if people will come asking them for charity: "And they turned away." If in the past they perceived themselves as members of society, now because of their fear of being asked for charity, they succumb to their own will more and more, and start to forget their promise to Allah as well as their relationships with society: "And they are no longer indifferent."

\subsubsection{Surah Al-Baqarah Verse 268}

"Satan promises (to frighten) you with poverty and orders you to commit crimes (miserliness); while Allah makes for you His forgiveness and gifts. And Allah is Vast (His grace), Allknowing”. Ibnul Qoyyim says that one is the promise of Allah, and the other is the promise of Satan. Let the miser and the munafiq decide which of the two promisesthey will prefer, they will find calming to their hearts, and they will find bringing to them happiness. Allah wills goodness for whomever He wants and abandons whomever He wants, and $\mathrm{He}$ is Most Vast (in His gifts), Most Knowing. If you are accustomed to doing good with alms but, then you start to hold onto your wealth in fear of poverty, know that Satan has taken over that interest.

A miserly attitude and choosing bad things for alms, comes from Satan who breathes worry into you about poverty, deceives you with a miserly attitude and orders you to commit immorality and violations against Allah. And Allah promises you for the alms that you pay, in the form of forgiveness for your sins and bounty. Allah is Most Vast in His grace, and $\mathrm{He}$ knows your deeds and intentions.

\subsubsection{Surah Al-Furqan Verse 67}

"And people who when they spend (property), they are not excessive, and not (also) stingy, and are (in their spending) in the middle of that." The daily life habit of 'Ibadur Rahman is explained, as follows: when he spends his wealth, he is not 
careless, and excessive beyond the required, and neither is he miserly, he spend in a balanced manner in the middle. He is not carelessly generous so that his treasures are depleted erratically, because of the consideration of his immature mind, not thinking about the future, and neither is he miserly for miserliness too is a disease.

The next characteristic is not too extravagant in giving away. Among Allah's servants who are most compassionate are people who, when they invest their wealth, do not overdo it by squandering the wealth, because this behavior is what Satan wants, and who are not stingy and cause the public to hate, they are between the two extremes naturally. This describes a religion that is in the middle, moderate, and balanced between the interests of individuals and society.

\subsubsection{Surah Al-Lail Verses 8-11}

"And as for whoever is naughty and feels that everything is enough." (verse 8) "and denies there is goodness." (verse 9). There are three things here that will bring harm. The first; is bakhil that is, when people do not want to spend their belongings to help someone who deserves to be helped and do not want to use their belongings to do amal jariah, because their lives have been enhanted by their belongings. People accumulate wealth as master of it. However, the miser collect belongings to be controlled by the belongings themselves, so that their hearts become closed, they no longer know love, nor shilatur-rahmi. Secondly, we feel that everything is sufficient, that is people shut themselves in for fear of being hit! Sometimes they are not happy to accept help from others, for fear that later they will have to return the favor. As a consequence of the collapse of souls with these two diseases, is the start of the third disease, namely (3) denying the existence of goodness. They do not believe that values of goodness exist in this world. It is hoped that goodness of humans relations with Allah, and the goodness that is found in this world, will also be found in the hereafter.

Shaykh Muhammad Abduh wrote that the meaning of easy is to get into trouble; each step does not bring up but brings down, covered by the path of humanity and fallings in a low degree of beastliness until one is wallowing in sins; "And not his wealth will be able to help him, if he falls." (Verse 11). If you want to rise again from the midst of sin, or if you fall into disarray because of miserliness, you cannot redeem it with the treasures that have been kept, because it is too late. First you earn it, but later you regret it as it no longer has any use.

\section{DISCUSSION}

The personality in the Al-Qur'an perspective needs to be studied with the consideration that the Al-Qur'an is a spark of Allah's intelligence that deserves to be used as a source of guidance of values of life for humans. The Al-Qur'an provides a comprehensive view that humans have physical, soul, mind, heart and spirit potentials. Thus there needs to be a study of the Al-Qur'an, especially of verses that are closely related to psychology. In this case, verse about gratitude and stinginess belong to the realm of human personality in social life. The purpose of this research is to bring up a new perspective in psychology under the influence of the Al-Qur'an. It will fill the gap in psychology for the good of humans and society. The study of the human psyche is a useful scientific activity and should be encouraged like other sciences.

\section{CONCLUSION}

Verses about gratitude include verses that ordain people to always be grateful (i.e., Luqman verse 12, Al-Baqarah verse 152, and Az-Zumar verse 66), a verse about that encourage people to give thanks (i.e., Al-Qamar verse 35), a verse on the rewards for people who are grateful (i.e., Al-Imran verse 145), a verse on the motivation to be grateful (i.e., Al-Qasash verse 73), and other verses about gratitude (i.e., An-Nahl verse 78, Ibrahim verse 7, Al-Furqan verse 62, and AlBaqarah verse 172.

As for verses about the miser or miserliness, this research include Muhammad verse 38, An-Nisa verse 37, Al-Isra 'verse 100, Al-Hadid verse 24, At-Taghabun verse 16, AtTaubah verse 76, Al-Baqarah verse 268, Al-Lail verses 8-11, Al-Furqan verse 67, and Al-Imran verse 180.

\section{REFERENCES}

[1] Aisyah, Asti and Rohmatun Chisol. Gratitude Relates to Psychological Well-Being in Primary School Honorary Teachers. Projection Journal, Vol. 13 (2) 2018, 109-122.

[2] Ayun, Qurrotu. Education \& Family Care in Shaping Child Personality Development: Islamic Developmental Psychology Perspective. Journal of Attarbiyah, Volume 26, 2016, pp. 91-11891.

[3] Bima Saputra, Imron. Educational Values in Surah AlHadid. Islamic Education Articles 2020.

[4] Bolotio, Rivai et al. Basics of Islamic Education in Surah Luqman Verses 12-19 According to Ibn Kathir's Tafsir.

[5] Fatmawati. The Role of the Family in the Formation of Islamic Personality for Adolescents. RISALAH Journal, Vol. 27, No. 1, June 2016: 17-31.

[6] Hidayat, Aat. Psychology and Human Personality: The Perspective of the Qur'an and Islamic Education. Research Journal, Vol. 11, No. 2, August 2017.

[7] Hidayat, Tatang et al. The Meaning of Gratitude Based on Digital Thematic Study of the Qur'an and Its Implications in Moral Education in Elementary Schools. Journal of Basic Education Vol. IV No. 01 of 2019.

[8] Muwafik Saleh, Akhmad. From Intrapersonal to Interpersonal: Between Generous and Bakhil. Clear and Educating Discourse 2019.

[9] Nasution, Zulkipli. The Concept of Moral Education in the Alquran to Build Student Character. Al-Fatih: Journal of Islamic Education and Education.

[10] Nihayah, Ishmatun. Internalization of Grateful Characters to Increase Student Motivation. Unpublished article

[11] Nujuludin, Djudju. Religion Shapes Educational Personality and Leadership Style. Garut University Education Journal.

[12] Nurmayani. Qalbiah's Intelligence in Islamic Psychology. Journal of Community Service, Vol. 19 Number 72 Year XIX June 2013.

[13] Renshaw, Tyler L. and Dana K. Rock. Effects of a brief grateful thinking intervention on college students' mental 
health. Mental Health \& Prevention 9 (2018) 19-24. doi.org/10.1016/j.mhp.2017.11.003

[14] Sandowil, Oktatul. Identification of the Verses About Stingy in the Al-Qur'an. Islamic Counseling Guidance Article 2018.

[15] Schlosser, A.E., The Sweet Taste of Gratitude: Feeling Grateful Increases Choice and Consumption of Sweets, Journal of Consumer Psychology (2015), doi: 10.1016 / j.jcps. 2015.02.006.

[16] Wörle, Monika et al. Paying it back and forward: The impact of experiencing and observing others 'sharing and stinginess on preschoolers' own sharing behavior and expectations. Journal of Experimental Child Psychology 2020.

[17] Neto, Fe'lix. Forgiveness, personality and gratitude. Personality and Individual Differences 43 (2007) 2313 2323. doi:10.1016/j.paid.2007.07.010

[18]Wood, Alex M. Conceptualizing gratitude and appreciation as a unitary personality trait. Personality and Individual Differences 44 (2008) 621-632. doi:10.1016/j.paid.2007.09.028

[19] Zhang, Jia Wei. Grateful people are happier because they have fond memories of their past. Personality and $\begin{array}{llll}\text { Individual Differences } 152 \quad \text { (2020) } & 109602 .\end{array}$ doi.org/10.1016/j.paid.2019.109602 